Western University Scholarship@Western

1985

\title{
Capital Controls and Fiscal Policy in the World Economy
}

Jeremy Greenwood

Kent P. Kimbrough

Follow this and additional works at: https://ir.lib.uwo.ca/economicsresrpt

Part of the Economics Commons

Citation of this paper:

Greenwood, Jeremy, Kent P. Kimbrough. "Capital Controls and Fiscal Policy in the World Economy." Department of Economics Research Reports, 8513. London, ON: Department of Economics, University of Western Ontario (1985). 
ISSN: 0318-725X

ISBA: 0-7714-0658-4

RESEARCH REPORT 8513

CAPITAL CONTROLS AND FISCAL POLICY IN THE WORLD ECONOMY*

by
Jeremy Greenwood
and
Kent P. Kimbrough

Jeremy Greenwood

University of Western Ontario and

Rochester Center for Economic Research

and

Kent P. Kimbrough

Duke University

July, 1985

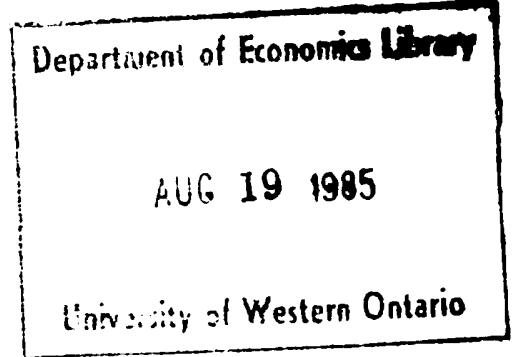

Forthcoming, Canadian Journal of Economics

*Helpful comments from two anonymous referees are gratefully acknowledged. Discussion in workshops held at Duke University, Iowa State University, Queen's University, Vanderbilt University, VPI, UCLA, and the University of Western Ontario has also been useful. 


\section{Abstract}

An intertemporal utflity maximization framework is employed to model a world economy with capital controls. The effects of fiscal policy in such an environment are examined. Several results emerge concerning the international transmission of fiscal policy under capital controls and the nature of comovements in macroeconomic aggregates such as output, employment, consumption, and investment. For instance, it is shown that movements in real interest rates can be negatively associated across countries under capital controls in contrast to the positive association which characterizes regimes allowing free capital flows. This is a consequence of the fact that while the intertemporal substitution effects arising from movements in real interest rates serve to generate positive comovements in macroeconomic aggregates when capital flows are unrestricted, they can operate to induce negative comovements when capital controls are present. Some of the paper's other results concern the implications of capital controls for Ricardian equivalence, the role of financing decisions in the international transmission process under capital controls, and the effect of capital controls on the magnitude of fiscal induced fluctuations throughout the world econory.

Jeremy Greenwood Department of Economics University of Western Ontario London, Ontario N6A 5C2 Canada
Kent P. Kimbrough Department of Economics Duke University Durham, NC 27706 U.S.A. 


\section{Introduction}

For quite some time now there has been considerable interest in the channels through which monetary and fiscal policies enacted in one country are transmitted to others. Policymakers are concerned with how the policies of their trading partners influence economic activity in their own country and with the proper response to these effects should they be deemed undesirable. During the 1970s most of the attention was focused on the International transmission of inflation and monetary policy [see, for instance, the papers in Darby et al. (1983)]. This was, of course, a consequence of the high rates of inflation experienced by several of the world's major industrial countries during this period. In contrast, the 1980 s have, to this point, been a decade in which attention has focused on the international transmission of fiscal policy in general and budget deficits in particular.

For many years the standard references on the international transmission of monetary and fiscal policies were variants of Mundell (1968). However, the concern over U.S. budget deficits in the past few years has prompted renewed interest in the topic of fiscal policy and the international transmission process as exemplified by Persson $(1982,1983)$ and Frenkel and Razin $(1985 \mathrm{a}, \mathrm{b})$. One element these papers have in comnon is the assumption that wurid capital markets are fully integrated in the sense that there are no impediments to international capital flows.

While capital markets have become more integrated in the past few years, impediments to international capital flows in the form of taxes and quantitative restrictions continue to be important, and are likely to remain so in the future. As Tables 1 and 2 illustrate, capital controls are highly prevalent in today's world economy. Of the seven major industrial countries listed in Table l, four (France, Italy, Japan, and the United Kingdom) had 
capital controls (i.e., quantitative restrictions on capital flows) virtually throughout the entire period from 1966-1982. This does not include taxes levied on international capital flows such as the U.S. Interest Equalization Tax that was in effect from 1963 to 1973, or less formal arrangements such as the Voluntary Foreign Credit Restraint Program the U.S. had from 1965-1974 for the purpose of protecting the U.S. balance of payments by limiting the acquisition of foreign assets. Table 1 suggests that not only are capital controls an important feature of the economic landscape, but that the major industrial countries can be divided into two groups - those that regularly restrict access to world capital markets and those that allow much freer capital flows. Table 2 confirms this picture for all IMF member countries. Capital controls existed in $72 \%$ of these countries throughout the entire five-year period from 1978-1982, while $19 \%$ of these countries had no capital controls during that period. The figures in Table 2 further indicate that in recent years a bit more than three-quarters of all IMF members have typically had capital controls at any one time.

Given the prevalence of capital controls in the world economy, it is important to incorporate them rigorously into the discussion of the international transmission process. That is the purpose of this paper. Earlier work by Morgenstern (1959) on the International propagation of business cycles hints at the type of economic phenomena that the incorporation of capital controls into the discussion of the international transinission process may help to explain. Morgenstern used NBER reference cycle series for France, Germany, the United Kingdom, and the United States to compare the timing of business cycles during the periods 1879-1914 and 1919-1932. He found that prior to World War I the four countries were in the same phase (expansion or contraction) during $53.5 \%$ of all months, while during the interwar years the 


\section{Introduction}

For quite some time now there has been considerable interest in the channels through which monetary and fiscal policies enacted in one country are transmitced to others. Policymakers are concerned with how the policies of their trading partners influence economic activity in their own country and with the proper response to these effects should they be deemed undesirable. During the 1970s most of the attention was focused on the International transmission of inflation and monetary policy [see, for instance, the papers in Darby et al. (1983)]. This was, of course, a consequence of the high rates of inflation experienced by several of the world's major industrial countries during this period. In contrast, the 1980 s have, to this point, been a decade in which attention has focused on the international transmission of fiscal policy in general and budget deficits in particular.

For many years the standard references on the international transmission of monetary and fiscal policies were variants of Mundell (1968). However, the concern over U.S. budget deficits in the past few years has prompted renewed interest in the topic of fiscal policy and the international transmission process as exemplified by Persson (1982, 1983) and Frenkel and Razin (1985a,b). One element these papers have in common is the assumption that wurid capital markets are fully integrated in the sense that there are no impediments to international capital flows.

While capital markets have become more integrated in the past few years, impediments to international capital flows in the form of taxes and quantitative restrictions continue to be important, and are likely to remain so in the future. As Tables 1 and 2 illustrate, capital controls are highly prevalent in today's world economy. Of the seven major industrial countries listed in Table l, four (France, Italy, Japan, and the United Kingdom) had 
capital controls (i.e., quantitative restrictions on capital flows) virtually throughout the entire period from 1966-1982. This does not include taxes levied on international capital flows such as the U.S. Interest Equalization Tax that was in effect from 1963 to 1973, or less formal arrangements such as the Voluntary Foreign Credit Restraint Program the U.S. had from 1965-1974 for the purpose of protecting the U.S. balance of payments by I1miting the acquisition of foreign assets. Table 1 suggests that not only are capital controls an important feature of the economic landscape, but that the major industrial countries can be divided into two groups -- those that regularly restrict access to world capital markets and those that allow much freer capital flows. Table 2 confirms this picture for all IMF member countries. Capital controls existed in $72 \%$ of these countries throughout the entire five-year period from 1978-1982, while $19 \%$ of these countries had no capital controls during that period. The figures in Table 2 further indicate that in recent years a bit more than three-quarters of all IMF members have typically had capital controls at any one time.

Given the prevalence of capital controls in the world economy, it is important to incorporate them rigorously into the discussion of the international transmission process. That is the purpose of this paper. Earlier work by Morgenstern (1959) on the international propagation of business cycles hints at the type of economic phenomena that the incorporation of capital controls into the discussion of the international transinission process may help to explain. Morgenstern used NBER reference cycle series for France, Germany, the United Kingdom, and the United States to compare the timing of business cycles during the periods 1879-1914 and 1919-1932. He found that prior to World War I the four countries were in the same phase (expansion or contraction) during $53.5 \%$ of all months, while during the interwar years the 


\section{Introduction}

For quite some time now there has been considerable interest in the channels through which monetary and fiscal policies enacted in one country are transmitted to others. Policymakers are concerned with how the policies of their trading partners influence economic activity in their own country and with the proper response to these effects should they be deemed undesirable. During the 1970s most of the attention was focused on the international transmission of inflation and monetary policy [see, for instance, the papers in Darby et al. (1983)]. This was, of course, a consequence of the high rates of inflation experienced by several of the world's major industrial countries during this period. In contrast, the 1980 s have, to this point, been a decade in which attention has focused on the international transmission of fiscal policy in general and budget deficits in particular.

For many years the standard references on the international transmission of monetary and fiscal policies were variants of Mundell (1968). However, the concern over U.S. budget deficits in the past few years has prompted renewed interest in the topic of fiscal policy and the international transmission process as exemplified by Persson $(1982,1983)$ and Frenkel and Razin (1985a,b). One element these papers have in cominon is the assumption that worid capital markets are fully integrated in the sense that there are no impediments to international capital flows.

While capital markets have become more integrated in the past few years, inpediments to international capital flows in the form of taxes and quantitative restrictions continue to be important, and are likely to remain so in the future. As Tables 1 and 2 illustrate, capital controls are highly prevalent in today's world economy. Of the seven major industrial countries Listed in Table 1, four (France, Italy, Japan, and the United Kingdom) had 
capital controls (i.e., quantitative restrictions on capital flows) virtually throughout the entire period from 1966-1982. This does not include taxes levied on international capital flows such as the U.S. Interest Equalization Tax that was in effect from 1963 to 1973, or less formal arrangements such as the Voluntary Foreign Credit Restraint Program the U.S. had from 1965-1974 for the purpose of protecting the U.S. balance of payments by IImiting the acquisition of foreign assets. Table 1 suggests that not only are capital controls an important feature of the economic landscape, but that the major industrial countries can be divided Into two groups -- those that regularly restrict access to world capital markets and those that allow much freer capital flows. Table 2 confirms this picture for all IMF member countries. Capital controls existed in $72 \%$ of these countries throughout the entire five-year period from 1978-1982, while $19 \%$ of these countries had no capital controls during that period. The figures in Table 2 further indicate that in recent years a bit more than three-quarters of all IMF members have typically had capital controls at any one time.

Given the prevalence of capital controls in the world economy, it is important to incorporate them rigorously into the discussion of the international transmission process. That is the purpose of this paper. Earlier work by Morgenstern (1959) on the International propagation of business cycles hints at the type of economic phenomena that the incorporation of capital controls into the discussion of the international transmission process may help to explain. Morgenstern used NBER reference cycle series for France, Germany, the United Kingdom, and the United States to compare the timing of business cycles during the periods 1879-1914 and 1919-1932. He found that prior to World War I the four countries were in the same phase (expansion or eontraction) during $53.5 \%$ of all months, while during the interwar years the 
TABLE 1

CAPITAL CONTROLS IN SEVEN INDUSTRIAL COUNTRIES, 1966-1982

\begin{tabular}{lc} 
Country & Years Capital Controls in Place \\
\cline { 2 - 2 } Canada & none \\
France & $1969-1982$ \\
Germany & none \\
Italy & $1967-1982$ \\
Japan & $1967-1979$ \\
United Kingdom & $1967-1979$ \\
United States & none
\end{tabular}

Source: Entries are based on the summary tables at the back of the IMF's

Annual Report on Exchange Arrangements and Exchange Restrictions, 1967-1983

issues. 


\section{TABLE 2}

CAPITAL CONTROLS IN IMF MEMBER COUNTRIES, 1978-1982

\begin{tabular}{lccc} 
& $\begin{array}{c}\text { \% with capital } \\
\text { controls }\end{array}$ & & $\begin{array}{c}\text { \% with capital } \\
\text { controls }\end{array}$ \\
\cline { 2 - 3 } all five years & 72 & 1978 & 77 \\
four years & 3 & 1979 & 76 \\
three years & 3 & 1980 & 76 \\
two years & 1 & 1981 & 78 \\
one year & 2 & 1982 & 79 \\
no years & 19 & &
\end{tabular}

Source: Same as Table 1, 1979-1983 issues. 
four countries were in the same phase only $35.6 \%$ of the time. Morgenstern attributed the decline of the international business cycle during the interwar years to "the effects of World War I" (he is not very specific on what exactly he means by this), but he went on to argue that a key difference between the two periods that might account for his results was that autarchic policies, especially with respect to capital movements and currency convertibility, played a more prominent role during the interwar years than ever before. Although not conclusive evidence on the Impact of capital controls on the international transmission process, Morgenstern's findings are provocative and they are Indicative of the sorts of results one might hope for when blending capital controls into a discussion of the international transmission of fiscal policy as is done here.

The remalnder of the paper 1s organized as follows. An outline of the basic environment which is assumed to characterize the world economy is undertaken in Section II. In Sections III and IV the representative agents' decision-rules and the model's world general equilibrium are presented. The Ricardian equivalence theorem is also discussed. The effects of domestic and foreign fiscal policies in the presence of capital controls are examined in Sections $V$ to VIII. The Importance of government financing decisions is stressed, and special attention is paid to the comovements in consumption, output, interest rates, and welfare levels which occur across countries in response to various fiscal shocks. Also, the magnitudes under capital controls of fiscal induced fluctations throughout the world are examined. Some concluding remarks are offered in Section IX. 


\section{The World Environment}

Imagine a two country, two period, single good world economy in which each economy is inhabited by a representative agent whose goal is to maximize his lifetime welfare. Consider the domestic economy first. The representative agent's sole source of income in period $t$ is derived from the production of a perishable good, $y^{t}$, which can be traded on world markets. The production function is given by $y^{t}=w^{t} \ell^{t}+h\left(i^{t}\right)$ where $l^{t}$ and $i^{t}$ are the amounts of period-t labor and capital inputs used in production, $w^{t}$ is the marginal product of labor and $h(\cdot)$ is a positive, increasing concave function.

The agent has the opportunity to participate on an international bond market. It is assumed, however, that the domestic government limits the amount of borrowing that domestic residents can undertake on this market. That is, there are capital controls in place. In the first period the domestic agent can purchase or sell real bonds which yield a real return of . r. With capital controls in place, there is no need for the domestic real interest, $r$, and the world real interest rate, $r^{*}$, to be the same. For instance, if the domestic government is artificially restricting the volume of private sector borrowing on world markets, the domestic real interest rate would exceed the world rate dus to the induced scarcity of credit. The domestic real interest rate, $r$, can be thought of as being constituted by two components. The first is the world real interest rate, $I^{\star}$. The second is the licensing fee which the domestic government charges for transactions on world capital markets. It is assumed that licenses are auctioned off competitively, so that the price of a license to issue a one unit real bond on the international market is $\left(r-r^{*}\right)$, a fee which is paid in the second period. Obviously, then $r=r *+(r-r *)$.

The individual also has the option of investing donestically in physical capital. In particular, 1 units of output invested in the first period 
yleld $h(1)$ units of period-two output. It is straightforward to show that optimal first-period investment dictates that $\delta h_{1}(i)=1$ so that firstperiod capital accumulation can be written as an increasing function of the domestic, discount factor, $\delta \equiv 1 /(1+r)$. Specifically, $i=h(\delta)$ with $i_{\delta}=-h_{i} / h_{i i}>0$. (It is assumed that the initial capital stock is zero so there is no need to add a superscript to 1.)

In each period the government undertakes a certain amount of unproductive government expenditure, ${ }^{1} g^{t}$, and levies taxes in the amount, $\tau^{t}$. Like any other actor in the economy, the government must satisfy a budget constraint. Its within period budget contraints are

$$
g^{1}=\tau^{1}+h+f \text { and } g^{2}+h(1+r)+f\left(1+r^{*}\right)=\tau^{2}+\left(r-r^{*}\right) z \text {, }
$$

where $h$ is the real amount of first-period borrowing the government does at home, $f$ is the amount of borrowing it undertakes on international markets, and $z$ is the private sector's (restricted) level of international borrowing. Before proceeding further, it should be noted that the foreign country is taken to be similar in structure to the domestic economy except that its government does not impose capital controls.

III. The Individual's Maximization Problem

The representative domestic agent's goal is to maximize his lifetime utility $u=u\left(c^{1}, \ell^{l}, c^{2}, \ell^{2}\right)$ subject to his budget constraint

$$
c^{1}+i(\delta)+\delta c^{2}=w^{1} \ell^{1}+\delta w^{2} \ell^{2}+\delta 11(i(\delta))-i^{1}-\delta \tau^{2}
$$

where $c^{t}$ is the agent's period-t consumption. The dual to the agent's 
cholce problem generates his expenditure function, 2

$$
E\left(1, \delta, w^{1}, \delta w^{2}, u\right) \equiv \min \left\{c^{1}+\delta c^{2}-w^{1} l^{1}-\delta w^{2} \ell^{2}: u\left(c^{1}, l^{1}, c^{2}, l^{2}\right)>u\right\}
$$

Differentiation of the expenditure function with respect to its first four arguments ylelds. the following compensated consumption demand and labour supply functions:

$$
\begin{aligned}
& c^{1}=c^{1}\left(1, \delta, w^{1}, \delta w^{2}, u\right) \\
& (-)(t)(+)(t)(t) \\
& c^{2}=c^{2}\left(1, \delta, w^{1}, \delta w^{2}, u\right) \\
& (+)(-)(+)(+)(+) \\
& \ell^{1}=\ell^{1}\left(1, \delta, w^{1}, \delta w^{2}, u\right) \\
& (-)(-)(+) \quad(-)(-) \\
& e^{2}=e^{2}\left(\underset{(-)}{1}, \delta, w^{1}, w^{2}, \underset{(-)}{u}\right) .
\end{aligned}
$$

The sign under the argument in one of these supply or demand functions shows the sign of the partial derivative of that function with respect to the argument in question. In signing the arguments substitutability and normality have been assumed to prevall.

The representative forelgn agent faces an analogous maximization problem. The dual to the forelgn Individual's maximization problem generates his expenditure function, from which his compensated consumption demand and labor supply functions can be acquired. 
IV. World General Equilibrium

Equilibrium requires that all markets clear in each period. To begin with, focus on the domestic economy. The hose country's economy-wide budget constraint is obtained by substituting the government's budget constraints, (1), into (2). This yields

$$
c^{1}+1+g^{1}+\delta c^{2}+\delta g^{2}=w^{1} \ell^{1}+\delta w^{2} \ell^{2}+\delta h(i)+\left(1-\frac{\delta}{\delta \star}\right)(z+f)
$$

which implies from (3) that in equilibrium

$$
E\left(1, \delta, w^{1}, \delta w^{2}, u\right)+i(\delta)+g^{1}+\delta g^{2}=c h(i(\delta))+\left(1-\frac{\delta}{\delta^{*}}\right)(z+f)
$$

Next, note that for the domestic econoty the excess of first-period spending, $c^{1}+i+g^{1}$ over income, $w^{1} \ell^{1}$, equals the capital account or the total amount of foreign borrowing, $z+f$, iaplying

$$
b \equiv z+f=c^{1}\left(1, \delta, w^{1}, \delta w^{2}, u\right)+i(\delta)+g^{1}-w^{1} \ell^{1}\left(1, \delta, w^{1} \delta w^{2}, u\right) .
$$

Under capital controls the total amount of private sector borrowing, $z$, is regulated by the government. Therefore, the overall the capital account, $b \equiv z+f$, is a policy variable. Letting $\tilde{b}$ denote the government's target level for the capital account and requiring $b=\tilde{b}$, equation (7) can be thought of as determining the market discount factor, $\delta$, given the level of domestic welfare, $u$, determined by (6). For the sake of argument it is assumed that the government is limiting the amount of borrowing the domestic economy is undertaking on the internationa: market and that the home country is currently a net debtor to the rest of the world (i.e., it is assumed $\tilde{b}$ is positive). 
Several important features of capital controls are apparent immediately from (6) and (7). First, relaxing capital controls and increasing public sector borrowing from abroad are equivalent policies. This can be seen by noting that $z$ and $f$ always enter additively in (6) and (7). Thus what matters from the economy's point of view is not who borrows from abroad but the total amount of international borrowing the country as a whole undertakes. Second, Ricardian equivalence between lump sum taxes and foreign borrowing by the government breaks down under capital controls. This is because by borrowing from abroad the government can effectively relax the economy's overall foreign borrowing constraint. ${ }^{3}$ This is an example of a case discussed by Barro (1974) where Ricardian equivalence fails to hold because the government is a more efficient intermediary than the private sector. The only difference is that here this comparative advantage arises from a policy-induced distortion whereas in Barro's discussion a "natural" cost advantage is involved. Third, for familiar reasons, Ricardian equivalence contlnues to hold between lump sum taxes and domestically issued public debt. Fourth, there is a distinction between government purchases financed by taxes or domestically issued public debt, what will be called domestically financed government purchases, and government purchases financed by foreign issues of public debt. That is, a switch from domestically to internationally financed government purchases has real effects. These effects arise because of the role played by public sector borrowing in relaxing the economy's overall borrowing constraint.

A set of equations similar to (6) and (7) holds for the foreign country:

$$
E *\left(1, \delta *, w *^{1}, \delta *_{w} \star^{2}, u^{*}\right)+i *(\delta *)+g \star^{1}+\delta * g \star^{2}=\delta * h *(i *(\delta *))
$$




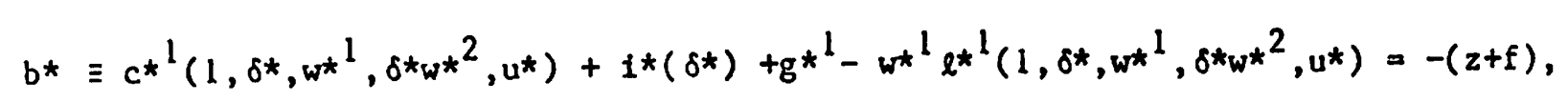

where an asterisk being attached to a varlable (and later sometimes an equation, number) denotes that its foreign magnitude (equivalent) is being discussed, and equilibrium in the world bond market implies $b *=-(z+f)$. The difference between the righthand side of (8) and (6) arises because the foreign country does not impose capttal controls and consequently earns no revenue through licensing fees.

Equations (6), (7), (8) and (9) determine equilibrium values for $\delta, u$, $\delta^{*}$ and $u^{*}$. This allows for the assignment of values to the model's other endogenous variables, $c^{1}, c^{2}, \ell^{1}, \ell^{2}, i, c^{\star}, c^{\star^{2}}, \ell^{\star}, \ell^{\star^{2}}$ and $i^{*}$.

\section{v. Bond Financed Tax Cuts}

Consider a period one tax cut by the donestic government which is inanced entirely by floating debt on the international bond market (i.e., let $\left.-d T^{1}=d f=d \tilde{b}\right)$. This policy is easily seen to be equivalent to easing capital controls, given the previous irrelevance proposition between private and public sector foreign borrowing. Under perfect capital mobility this traditional Rj.cardian experiment would have no real effects because domestic agents, realizing the present value of their tax burden had not changed, would simply use the proceeds of the current tax cut to purchase the newly issued public debt. As a result total domestic borrowing would remain unchanged and world real interest rates as reflected in $\delta=\delta^{*}$ would be unaffected. As will be seen, with capital controls in place this Ricardlan equivalence result does not hold.

To begin with, (8) and (9) imply that under capital controls the expansion in the domestic government's international debt is transmitted to the foreign market discount factor and welfare as follows: 


$$
d \delta * / d \tilde{b}=-1 /(d b * / d \delta *)<0
$$

and

$$
d u * / d \tilde{b}=-\left(\tilde{b} / E_{u}^{*} \delta *\right)(d \delta * / d \tilde{b})>0
$$

where $d b * / d \delta *$ represents the uncompensated impact of an increase in the foreign market discount factor, $\delta^{*}$, on foreign borrowing, b*. That 1s,

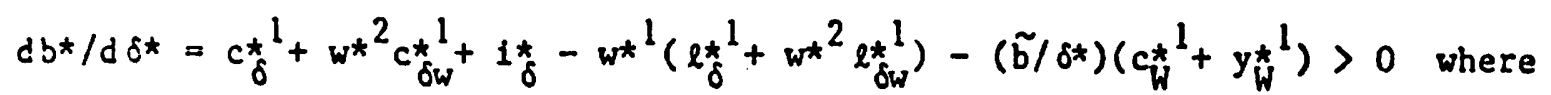
$c_{W}^{*}=c_{u}^{*^{l}} / E_{u}^{*}$ and $y_{W}^{k^{l}}=-w^{*^{l}} \ell_{u}^{*^{l}} / E_{u}^{*}$ are the foreign marginal propensities to spend on consumption and leisure, with the sign of this expression following from the assumption that in the foreign country first- and second-period goods are gross substitutes. As can be seen, the increase in domestic borrowing requirements on world markets depresses the foreign market discount factor, $\delta^{\star}$, or equivalently exerts upward pressure on the foreign real interest rate, $\boldsymbol{r}^{\star}$. The extent of the fall in the foreign market discount factor is regulated by the responsiveness of foreign borrowing to changes in the foreign market discount factor. The more willing foreigners are to reduce their borrowing when their market discount factor falls, 1.e., the larger $d b * / d \delta^{*}$, the smaller the required drop in $\delta^{*}$. Under the maintained hypothesis that the foreign country is a net crepditor $(\tilde{b}>0)$, an Improvement in foreign welfare, $u^{\star}$, results as a consequence of the domestic government's fiscal action (trivially, if the foreign country was a net debtor 1 ts welfare would fall). This example illustrates that offsetting the effects of Increased deficit financing by one's trading partner, something many countries seem concerned with, is not necessarily the same thing as welfare maximization -- here foreign welfare rises precisely because the increased budget deficits are allowed to be transmitted In:ernationally.

The Impact of an increase in the domestic country's international debt on 
foreign macroaggregates can eastly be deduced from $\left(4^{*}\right),(10)$ and (11) to be:

$$
d c^{*} / d \tilde{b}=\left[c_{\delta}^{1}+w^{*} c_{\delta w}^{1}-(\tilde{b} / \delta *) c_{\tilde{w}}^{1}\right](d \delta * / d \tilde{b})<0
$$

and

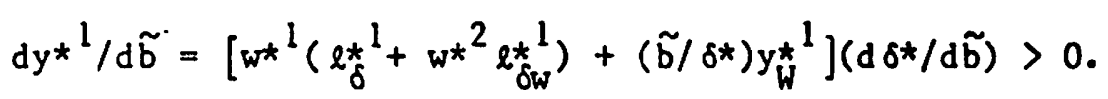

The sign of. the above expressions follow from the standard macroeconomic presumption that the substitution effects generated by an intertemporal price change dominate the income effects. To better understand the considerations involved here, focus on the response of first-period consumption as shown by (12). The term $c_{\delta}^{*^{1}}+w \star^{2} c_{\delta w}^{1}$ illustrates the negative substitution effect that a fall in the foreign market discount factor exerts on first-period consumption. The second term represents the positive wealth effect that a fall in the discount factor has on first-period consumption. Note that the substitution and wealth effects operate in opposite directions. Expression (13) can be interpreted in a sirilar manner.

The domestic government's bond financed tax cut is accompanied by a rise in the domestic market discount factor or a fall in the domestic real interest rate. In particular, from (6) and (7) it follows that

$$
d \delta / d \tilde{b}=\left[1-(1-\delta / \delta *)\left(c_{W}^{1}+y_{W}^{1}\right)\right] /(d b / d \delta)_{u}-\left[\left(c_{W}^{1}+y_{W}^{1}\right) /(d b / d \delta)_{u}\right](d \delta * / d \tilde{b})>0
$$

where $c_{w}^{1} \equiv c_{u}^{1} / E_{u}$ and $y_{w}^{1} \equiv-w^{l} \ell_{u}^{l} / E_{u}$, and $(d b / d \delta)_{u}$ represents the compensated effect of an increase in the domestic market discount factor, $\delta$, on domestic international botrowing, $b$, so that $(d b / d \delta)_{u} \equiv c_{\delta}^{1}+w^{2} c_{\delta w}^{1}+i_{\delta}$ - $w^{1}\left(2_{\xi}^{1}+w^{2} 2_{i w}\right)>0$. With capital controls in place pure domestic debt is a 
nontraded good and thus there is no income effect on domestic borrowing associated with a change in the domestic market discount factor. The domestic interest rate falls for two reasons. First, the effective loosening of capital controls, increases the net supply of loanable funds to the domestic economy [the first term in (14)]. ${ }^{4}$ Second, the negative wealth effect associated with the rise in the world real interest rate dampens "'e domestic demand for current borrowing (the second term).

A key result here, which can be seen from (10) and (14) is the negative comovement between domestic and foreign real interest rates. The possibility of negative comovements in interest rates is a salient characteristic of capital controls. In a world economy with fully integrated capital markets interest rates in national economies move in unison. This harmony in interest rate movements induces qualitatively similar intertemporal substitution effects across countries, and thus serves to generate positive comovements of national macroeconomic aggregates. In contrast, even with fully integrated capital markets the wealth effects associated with interest rate changes operate to offset the tendency toward positive correlation of macroaggregates arising from intertemporal substitution effects. For instance, a shock triggering a rise in world interest rates benefits creditor countries but hinders debtor ones. However, given the presumption that an intertemporal price change's substitution effect dominates its wealth effect, positive comovement in macroeconomic aggregates across countries occurs. (See Appendix A for a more formal analysis of the perfect capital mobility case.) In the presence of capital controls, however, just the opposite is true. The negative international transmission of intertemporal relative price.changes tends, via both intertemporal substitution effects and wealth effects, to generate negative comovement in macroeconomic aggregates. 
The change in domestic welfare can be calculated from (6) to be

$$
d u / d \tilde{b}=\left[(1-\delta / \delta *)+\left[\delta \tilde{b} /(\delta *)^{2}\right](d \delta * / d \tilde{b})\right] / E_{u} \geqslant 0
$$

The first term in braces on the righthand side of the above expression illustrates the Improvement in home welfare arising from the effective loosening of capital controls. As an aid to understanding this term, consider the following experiment. Suppose that the domestic government lets the agent increase his first-period consumption by a unit via borrowing on the international financial market. The unit increase in current consumption must be met by a $1 / \delta *$ unit reduction in second-period consumption so that the loan can be repaid. The agent values a unit of second-period consumption as being worth $\delta$ units of first-period consumption, however, so the net gain measured in terms of current consumption $1-\delta / \delta^{*}=\left(r-r^{*}\right) /(1+r)$. Finally, the second term in braces represents the drop in welfare due to the deterioration in the intertemporal terms of trade.

These results can be further elaborated on by relating them to the standard optimum tariff criterion. The above expression can be rewritten by using $(10)$, and the fact that $\tilde{b}=-b^{*}$, as

$$
\begin{aligned}
d u / d \tilde{b} & =\left\{(1 / \delta)-\left(1 / \delta^{*}\right)\left[1-\left(b^{*} / \delta^{*}\right)\left(d \delta^{*} / d b^{*}\right)\right]\right\} \delta / E_{u} \\
& =\left\{\left[\left(\delta^{*} / \delta\right)-1\right]+\left(b^{*} / \delta^{*}\right)\left(d \delta^{*} / d^{*}\right)\right\}\left(\delta / \delta * E_{u}\right) \geqslant 0 .
\end{aligned}
$$

The term $1 / j$ is the marginal valuation (in terms of future goods) of additional borrowing while $\left(1 / \delta^{*}\right)\left[1-\left(b^{*} / \delta^{*}\right)\left(d \delta^{*} / d b^{*}\right)\right]$ is the marginal cost of such borrowing. When financial flows are optimally restricted under capital 
controls, these two margins are equalized. In such a case the Implicit tax being exacted by capital controls on borrowing from foreign sources, $(\delta * / \delta)-1$, is set equal to the reciprocal of the elasticity of the foreign offer curve, $-\left(b^{*} / \delta^{*}\right)\left(d \delta^{*} / d^{*}\right)$. Note that $1+x=\left\{1+\left[\left(\delta^{*} / \delta\right)-1\right]\right\}\left(1+r^{*}\right)$ so that $(\delta * / \delta)-1$ can be thought of as the effective tax being levied on the forelgn gross interest rate. This is of course a standard optimum tariff type result. 5 Hence domestic welfare improves or deteriorates with a switch in government financing from domestic to foreign sources as the tax equivalent of capital controls is above or below the optimum level.

The 1mplications of the switch in government financing for domestic macroeconomic aggregates can be derived by using (14) and (16) along with the domestic consumption demand and labor supply functions. Without formally deriving these results, note that this sort of policy may lead to the negative comovement in macroeconomic aggregates that Morgenstern (1959) documented for the interwar years. As an example, suppose that the tax equivalent of domestic capital controls is above the optimum level so that the financing change improves domestic welfare. In this case both substitution and wealth effects work to expand domestic consumption and investment while output and employment contract. These movements are all in the opposite direction from those of their foreign counterparts. That is, in such circumstances negative internatlonal comovements in real 1nterest rates and macroeconomic aggregates arise. 6 Yet another Insight this example highlights is the possibllity that in an open economy with capital controls deficit financing, of the international variety, may be contractionary in the sense of reducing output and employment. These results run counter to those usually attributed to deficit financing in closed economies where output and employment are demand determined and government bonds are viewed as net wealth. 
VI. Domestically Financed Government Purchases

The impact of a temporary increase in current government expenditure, $\mathrm{g}^{1}$, which is financed from domestic sources -- some combination of lump-sum taxation and domestic bond financing -- is the subject of this section of the paper. It is readily apparent from (8) and (9) that capital controls prevent the international transmission of a domestic expansion financed entirely from home sources. This occurs because the forelgn country's only link with the domestic economy is through the current account which, under capital controls, is a regulated quantity.

From (6) and (7) is is easy to deduce the effects of a temporary shift in current government expenditure on domestic welfare, $u$, and the domestic market discount factor, $\delta$. Specifically, it can be shown that

$$
\mathrm{du} / \mathrm{dg}=-1 / \mathrm{E}_{\mathrm{u}}<0
$$

and

$$
\mathrm{d} \delta / \mathrm{dg} \mathrm{g}^{1}=-\left(1-c_{W}^{1}-y_{W}^{1}\right) /(d b / d \delta)_{u}<0
$$

As can be seen, welfare deteriorates while the domestic market discount factor (real interest) falls (rises). Next, it is readily apparent from (4) that current consumption, $c^{l}$, and employment, $l^{l}$, expand in response to the temporary upward shift in government expenditure. In particular, it follows that

$$
\begin{aligned}
& d c^{1} / d g^{1}=c_{\delta}^{1}\left(d \delta / d g^{1}\right)+c_{u}^{l}\left(d u / d g^{1}\right)<0, \\
& d \ell^{l} / d g^{1}=\ell_{\delta}^{l}\left(d \delta / d g^{1}\right)+\ell_{u}^{l}\left(d u / d g^{l}\right)>0 .
\end{aligned}
$$

Note that the wealth effect associated with the increased government expendi- 
ture, and the substitution effect, arising from the change in the real interest rate both work to curtail current consumption and stimulate current work effort. These results are identical to those which would obtain in a closed economy: LAn analysis, in a similar model, of the closed economy effects of fiscal shocks is contained in Aschauer and Greenwood (1985)]. This is not surprising since capital controls have effectively cut off the channel through which domestic impulses are transmitted to the foreign economy.

It is interesting to briefly compare the above results to those which would result if the domestic government taxed international capital flows rather than quantitatively restricting them. In particular, suppose that the domestic government imposes an ad valorem surcharge $\theta$ on the interest and principal payable on loans from abroad. In this case domestic and foreign gross real interest rates would be linked by the relationship $(1+r)=(1+\theta)\left(1+r^{*}\right)$ or, equivalently, $(1+\theta) \delta=\delta^{*}$. It is easy to show (see Appendix A for a formal analysis) that a transitory increase in current domestic government expenditure now drives up both domestic and foreign real interest rates. This induces intertemporal substitution effects which curtail first-period consumption and stimulate current output in both countries. As In the perfect capital mobility case (i.e., when $\theta=0$ ), intertemporal substitution effects generate positive cross-country covarlation in macroaggregates. For the foreign country the rise in its real interest has a positive wealth effect, since $1 t$ was assumed to be a net international creditor. This tends to stimulate its current consumption of goods and leisure. The effect on the domestic economy's welfare is ambiguous. On the one hand, the Lemporary rise in current domestic nonproductive government expenditure reduces welfare. On the other hand, the induced increases in the domestic country's international borrowing improves welfare when the tax rate, $\theta$, 
exceeds the level dictated by the optimum tariff criterion. (Again, see Appendix A for formal detalls.) For the perfect capital mobllity case, or more generally when $\theta<-(b * / \delta *) /(d b * / d \delta *)$, domestic welfare unambiguously falls on both accounts. This causes a further drop in current consumption and a rise in labor supply.

Whether domestic macroeconomic aggregates are more or less (In absolute terms) responsive to government spending shocks under capital controls vis a vis fully integrated capital markets is unclear. Since capital controls prevent incipient excess demands for or supplies of goods from being transmitted to world markets, the domestic real interest rate responds more strongly to temporary changes in government purchases than it would in a fully integrated world economy. As a result, capital controls tend to magnify the impact of temporary changes in government purchases by strengthening intemporal substitution effects. Running counter to this, however, is the fact that capital controls eliminate the deleterious wealth effect associated with the rise in the world real interest rates connected with the increased domestic government purchases. Hence the wealth effects associated with shifts in the intertemporal terms of trade are dampened by capital controls.

VII. Internationally Financed Changes in Government Purchases

Suppose that Instead of financing the temporary increase in government purchases domestically the home country decides to tap the world capital warket $\left(d \tilde{b}=d g^{l}\right)$. As can be seen from (8) and (9), this method of financing causes the domestic fiscal action to be transmitted internationally. In fact, the impact on the foreign country is again given by equations (10) to ( 13$)$. This emphasizes an Important difference in the international transmission process created by capital controls: With fully integrated capital markets 
financing decisions are 1rrelevant for the international transmission of fiscal policy. The crucial element is the type (anticipated or unanticipated, permanent or temporary) and magnitude of shifts in government purchases. Capital controls, however, turn things upside down. The crucial element for international transmission under capital controls is the method of financing; the type and magnitude of government purchases is largely irrelevant.

Comparing the international transmission of economic activity in the current case to that which would obtain in a fully integrated world economy (see Appendix A), it can be seen that the qualitative response of foreign variables to temporary changes in domestic government purchases is the same. Further investigation reveals, however, that under capital controls forelgn real interest rates are more sensitive to internationally financed temporary changes in domestic government purchases and hence foreign macroeconomic aggregates will experience larger fiscal induced fluctuations under capital controls. 7 Overall then, domestic fiscal induced fluctuations in the foreign economy may be magnified or mitigated when capital controls are enacted by the home country depending upon whether the fiscal actions are financed from domestic or international sources. The larger the share of domestic government purchases that (at the margin) is financed internationally, the more likely it is that the presence of capital controls will produce larger fluctuations in foreign macroeconomic aggregates in response to domestic government purchase shifts.

In assessing the domestic impact of temporary increases in government purchases financed by international sales of public debt, it is useful to realize that such a policy is equivalent to a domestically financed increase in government purchases plus a switch from domestic to international financing. Therefore, domestic behavior can be found by simply adding the 
results uncovered in the previous two sections. From (16) and (17) it is apparent that domestic welfare may rise or fall, although the former is a possibility only if the tax equivalent of capital controls is above the optimum level. It can also be shown that the domestic real Interest rate falls. Since foreign real interest rates $\mathrm{rise}$, internationally financed shifts in domestic government purchases under capital controls are characterized by negatively associated real interest rate movements.

To see that the domestic real interest rate does indeed fall, combine (14) and (18) to obtain

$$
\begin{aligned}
& \left(d \delta / d g^{l}\right)_{d \tilde{b}=d g} 1=-\left(1-c_{W}^{1}-y_{W}^{1}\right) /(d b / d \delta)_{u}+\left\{1-\left(c_{W}^{1}+y_{W}^{1}\right)[1-(\delta / \delta *)]\right\} /(d b / d \delta)_{u} \\
& -\left[\left(c_{W}^{l}+y_{W}^{l}\right) \delta \tilde{b} /(\delta *)^{2}(d b / d \delta)_{u}\right](d \delta * / d \tilde{b}) \\
& =\left(\delta / \delta^{*}\right)\left(c_{W}^{1}+y_{W}^{1}\right) /(d b / d \delta)_{u}-\left[\left(c_{W}^{1}+y_{W}^{l}\right) \delta \tilde{b} /\left(\delta^{*}\right)^{2}(d b / d \delta)_{u}\right](d \delta * / d \tilde{b})>0 .
\end{aligned}
$$

There are three forces at work here. First, the temporary increase in government purchases works to raise the domestic real interest rate by $-\left(1-c_{W}^{1}-y_{W}^{1}\right) /(d b / d \delta)_{u}$ as it would in a closed economy. Second, the effective easing of capital controls due. to the international financing of government purchases works to reduce the domestic real interest rate. Third, the rise in the foreign real interest rate is negatively transmitted to the home country. Note that the algebra indicates that the implicit easing of capital controls dominates the cendency for increased government purchases to raise the real interest rate. That is, international transmission aside, the domestic real interest rate tends to fall. The intuition underlying this result is readily apparent. Focusing on the second line of (19), the term $\delta / \delta \star$ is the dis- 
counted value of the future debt repayment obligations the economy incurs on (each unit of) its extra foreign borrowing. Smoothing behavior by the private sector implies that a portion of these obligations, $c_{W}^{1}+y_{W}^{1}$, will be financed by, reducing current consumption and increasing current output (1.e., reducing current leisure). Thus there is an excess supply of goods which must be eliminated by a fall in the domestic real interest rate. IIn going from the first to the second line of (19) $1-c_{W}^{1}-y_{W}^{1}$ terms cancel. This is because, after adjusting for wealth effects, the additional resources made available by the increased foreign borrowing just match the extra resources demanded due to the additional government purchases.]

Finally, as a general matter it is unclear whether internationally financed temporary increases in government will have (in absolute value terms) a stronger impact on domestic macroeconomic aggregates under capital controls or under fully integrated capital markets. The details of the argument follow directly from splicing together the results of the previous two sections. After doing this it appears ambiguous what effect imposing capital controls will have on the overall fluctuations in the domestic economy emanating from shifts in domestic fiscal policy. Notice, however, that if intertemporal substitution effects are strong enough it is again possible to observe negative rather than positive fiscal induced comovements in macroeconomic aggregates.

\section{Capital Controls and Foreign Fiscal Policy}

So far the focus has been on the international transmission of fiscal policies from a country with capital controls to the rest of the world. It is also of interest to know how fiscal policies enacted by the rest of the world are transmitted to a country with capital controls. As a backdrop for the comparisons that follow note that with fully integrated capital markets a 
temporary increase in forelgn government purchases raises the world real interest rate. Home welfare therefore falls, and it follows immediately that since substitution and wealth effects work in the same direction domestic output and employment expand while consumption and investment contract. Foreign welfare may move in either direction but as long as substitution effects dominate wealth effects, forelgn macroeconomic aggregates will be positively correlated with their domestic counterparts. (The detalls of the argument can be found in Appendix A.)

Under capital controls it is straightforward to show that

$$
\begin{aligned}
& d \delta * / d g *^{l}=-\left(1-c_{W}^{*}-y_{W}^{*}\right) /(d b * / d \delta *)<0 \\
& d u * / d g *^{1}=-\left(1 / E_{u}^{*}\right)-\left[\tilde{b} /\left(E_{u}^{*} \delta *\right)\right]\left(d \delta * / d g *^{1}\right) \geqslant 0, \\
& d c^{*} / d g^{1}=\left[c \star_{\delta}^{1}+w^{*} c_{\delta w}^{1}-(\tilde{b} / \delta *) c *_{W}^{1}\right]\left(d \delta * / d g^{*}\right)-c_{W}^{1}<0,
\end{aligned}
$$

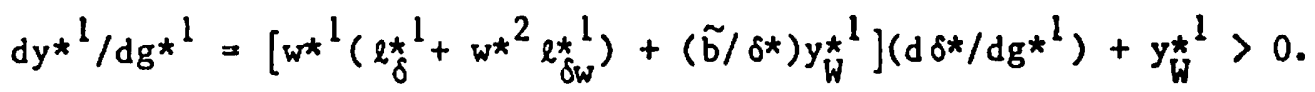

These results are qualitatively the same as in the absence of capital controls. A more detalled comparison of the above results with those arising in the perfect capital mobility case reveals that there is a proclivity for a temporary increase in foreign government purchases to raise real interest rates more under capital controls because none of the excess demand for goods can be transmitted to the home country. ${ }^{8}$ Therefore, under capital controls foreign macroeconomic aggregates may undergo wider swings in response to Eoreign fiscal shocks than they would with fully integrated capital markets. Combining this with the earlier discussion of the international transmission 
of domestic fiscal policy, it follows that the imposition of capital controls by the home country may result in more pronounced overall fiscal induced fluctuations in foreign macroeconomic aggregates. This possibility reflects the fact, that the imposition of capital controls severely curtalls trading opportunities -- there is thus a tendency for disturbances to have more pronounced effects under capital controls because there is less spillover to world markets.

Turning to the domestic economy, it can be seen from (6) and (7) that the domestic real interest rate falls and hence home welfare deteriorates:

$$
\begin{aligned}
& d \delta / d g *^{l}=-\left[\left(c_{W}^{1}+y_{W}^{1}\right) /(d b / d \delta)_{u}\right]\left[\left(\delta \tilde{b} /(\delta *)^{2}\right)\left(d \delta * / d g^{1}\right)\right]>0 \\
& d u / d g *^{1}=\left[\delta \tilde{b} / E_{u}(\delta *)^{2}\right]\left(d \delta * / d \star^{1}\right)<0 .
\end{aligned}
$$

Again real interest rate movements are negatively correlated under capital controls, at least under the maintained hypothesis that the home country is a net debtor on international capital markets. As can be seen the transmission of the forelgn fiscal shock to the domestic economy operates entirely through a wealth effects channel. It appears then that under capital controls wealth effects are more central to the transmission of foreign impulses to the domestic economy. This is because quantitative restrictions on international capital flows sever any direct link between domestic and foreign real interest rates. The increased importance of wealth effects in the international transmission of relative price changes is a general feature of trade under quantitative restrictions. An example concerning intratemporal relative prices can be found in Greenwood and Kimbrough (198'a), where it is shown that terms of trade fluctuations are transmitted negatively, via an income effect 
route, to countries with foreign exchange controls.

Also note that the induced substitution and wealth effects implied by (20) and (21) necessarily run counter to each other. This need not be the case when there is perfect capital mobility. For instance, when the domestic country is'a net debtor a temporary increase in current foreign government purchases induces wealth and substitution effects which reinforce each other. Additionally, by choosing a target level of zero for international borrowing, the domestic government could insulate the economy completely from foreign shocks. The potential insulation from foreign shocks afforded by capital controls, is, of course, one reason why they are so prevalent. Insulating an economy from foreign shocks does not necessarily correspond to maximizing welfare though. As has been shown, the level of the capital account, $\tilde{b}$, which maximizes the domestic economy's welfare is dictated by the standard optimum tariff criteria (assuming the absence of retaliation from the rest of the world). For a small open economy without distortions free trade in capital is thus superior to restricted trade. Thus the level of the capital account which affords the most Insulative power from foreign macroeconomic fluctuations for a country does not generally coincide with the level which maximizes its welfare. The upshot of this discussion is that it appears to be reasonable to conjecture that capital controls mute the effects of foreign fiscal shocks on domestic consumption, output, and other macroaggregates.

Since substitution and wealth effects run counter to one another, without restricting preferences the qualitative nature of domestic consumption, employment, and output movements cannot be pinned down. However, if preferences are assumed to be time separable, an assumption of ten employed in closed and open economy dynamic models, it can be shown that (the results for $c^{l}$ are worked out in detail in Appendix B) 


$$
\begin{aligned}
& d c^{1} / d g \star^{1}=\left[c_{W^{1}}^{1} \delta \tilde{b} /(\delta)^{2}(d b / d \delta)_{u}\right]\left(d \delta / d g \star^{1}\right)<0, \\
& d y^{1} / d k^{1}=-\left[y_{W^{1}}^{1} \delta \tilde{b} /(\delta)^{2}(d b / d \delta)_{u}\right]\left(d \delta / d g^{1}\right)>0 .
\end{aligned}
$$

Domestic consumption, employment, and output thus respond similarly to foreign fiscal policy under capital controls as they do in a fully integrated world economy. Hence under capital controls, when the home country is a net debtor, positive international comovements in output, employment, and consumption (but not investment) continue to occur in response to forelgn fiscal shocks. Negative association between the countries macroaggregates will occur, however, when the domestic economy is a net creditor. So once again, with capital controls in place it is possible to observe negative transmission of shocks between countries.

The above example highlights the importance of physical investment in the model. Somewhat surprisingly, with time separable preferences if investment is not included in the model temporary foreign government spending shocks have no impact on the domestic country's current consumption or output. (To see this set $1_{\delta}=0$ in the above two equations.) When the foreign real interest race rises, so does the domestic economy's second-period real interest payments on its foreign debt. With time separable preferences, the absence of domestic physical capital accumulation, and a regulated capital account, there is no intertemporal channel to allow for the smoothing of shocks over the first and second periods. Therefore, the burden of the rise in foreign real interest rates is absorbed entirely by second-period consumption and output. This restrictive nature of time separable preferences has been discussed in detail by Barro and King (1984).9

With the inclusion of physical capital in the model, the fall in the 
domestic real interest rate promotes an increase in first-period capital accumulation. This rise in capital accumulation is financed domestically by a fall in current consumption and an increase in current labor effort. The larger amount of current investment is then used to buffer the fall in secondperiod consumption and the required increase in that period's labor effort. Hence with capital controls in place, changes in domestic physical capital accumulation tend to play an important role in smoothing the impact of various shocks over time.

\section{Conclusions}

An examination of the effects of capital controls was conducted using a small-scale choice-theoretic general equilibrium model of the world economy. The effects of fiscal policy in such an environment were investigated by studying the responsiveness of the world economy to various types of fiscal shocks emanating both at home and abroad and comparing them to the fluctuations that would arise in the absence of quantitative restrictions on international financial transactions. To date not much work has been undertaken in international finance on the nature of capital, or other, controls. Hence the findings in this paper should be viewed as preliminary in nature. Some tentative conclusions are:

(i) In countries with capital controls Ricardian equivalence holds between taxes and domestically issued public debt but not between taxes and internationally issued public debt. This reflects the fact that sales of public debt on the world market represent an effective loosening of capital controls.

(ii) Consequently the method of financing government purchases, which is largely irrelevant for the international transinission process when capital 
markets are fully integrated, becomes a cruclal element when considering the international transmission of fiscal policies undertaken by countries with capital controls.

(iii) In the absence of capital controls intertemporal substitution effects tend to generate positive international comovements in macroeconomic aggregates such as output, employment, consumption, and Investment, while the wealth effects associated with intertemporal terms of trade changes create a tendency for negative comovements. If these wealth effects are not large (in a sense defined precisely in Appendix A), fluctuations in macroeconomic aggregates will be positively correlated across countries when capital markets are fully integrated. In contrast, capital controls sever the direct link between nation's real interest rates. In fact, as was shown, capital controls may lead to negatively correlated real interest rate movements. As a result, their imposition can generate intertemporal substitution effects working toward negative covement in macroeconomic aggregates. Also, for a country imposing capital controls the wealth effect associated with world interest rate changes has a more important role in transmitting the impact of such shifts to the economy.

(iv) Instituting a system of capital controls can help to Insulate a country from fiscal Induced fluctuations originating from abroad but has ambiguous implications for the size of fiscal induced fluctuations of domestic origin. It should be remembered that insulating an economy, does not necessarily colncide with maximizing its welfare. Countries allowing free capital flows may find fiscal induced fluctuations in their macroeconomic aggregates more pronounced when their trading partners impose capital controls.

It should be borne in mind that these results apply not only to countries operating a formal system of capital controls but to others interferring with 
capital flows as well. For Instance, the results also apply to countries that tax international capital flows in order to attain a target capital account. Unless tax rates are actively managed to attain quantitative targets, however, taxing capital flows will have more in common with a system of integrated capital markets than with a system of capital controls. As was discussed this is because taxes on capital flows drive a wedge between domestic and world real interest rates but leave the link between them intact. Capital controls, on the other hand, sever this link so that capital markets take on the characteristics of markets for nontraded goods. Therefore, real interest rate movements remain positively correlated when capital flows are taxed but become negatively correlated when capital controls are put in place. In addition to systems of taxes on capital flows aimed at a target capital account, dual exchange rate systems also have the same implications for the international transmission process as capital controls. This follows from the fact that dual exchange rates can be demonstrated to be equivalent to capital controls [see Adams and Greenwood (1985)]. In light of the fact that roughly three quarters of the world's countries have capital controls, and many more tax capital flows or operate dual exchange rate systems, the results outlined in this paper should have widespread applicability in interpreting international comovements in real interest rates, output, employment, consumption, and Investment.

One possibly troubling implication of the results presented here is that In the absence of capital controls there should apparently be no international concern about the methods a country uses to finance its government purchases: the only concern should be with the overall level and timing of these purchases. At the root of this result is the fact that with free capital flows Ricardian equivalence holds. When Ricardian equivalence is broken the inter- 
national transmission of budget deficits, per se, becomes an important issue as is highlighted by Frenkel and Razin (1985b). In their work an overlapping generations model where agents without a bequest motfve die stochastically is employed.' The fact that individuals' lifetimes are uncertain results in private borrowing and lending activity being undertaken at effective interest rates which reflect the probability of dying. The government, being immortal, borrows and lends at risk-free interest rates. The divergence between private and public interest rates violates the assumptions necessary to ensure the RIcardian equivalence theorem holds.

An alternative departure from the Ricardian framework would be to assume that revenues must be raised by distortioning income taxes. Here the government's financing decisions matter since the timing of taxes has important real effects. 10 If the government raises its revenues in a manner that maximizes national welfare, the time profile of income taxes will be dictated by a Ramsey tax rule. The general outcome is that taxes should be smoothed over time so as to minimize the deadweight burden of taxation, a point Barro (1979) has emphasized. This would yield an optimal profile for the public debt and a richer analysis of the international transmission of fiscal policy. Countries might have special concerns about increased budget deficits in the nations they trade with in as much as they may be associated with unusually large levels of government purchases (perhaps because a scaling down of future government activity is expected). This is one possible area for future research on the International transmission of fiscal policy. 


\section{Appendix A}

Suppose that instead of imposing capital controls the domestic government levies an ad valorem surcharge in the amount $\theta$ on the principal and interest payable on international borrowing by domestic residents. Here the domestc and foreign market discount factors will be related by the formula $\delta=\delta * /(1+\theta)$. The world's general equilibrium is now completely described by the following four equations which implicitly define solutions for $u, \delta$, $u^{*}$, and $\delta *$.

$$
\begin{aligned}
& E\left(1, \delta, w^{1}, \delta w^{2}, u\right)+i(\delta)+g^{1}+\delta g^{2}=\delta h(i(\delta)) \\
& +(\theta /(1+\theta))\left[c^{1}\left(1, \delta, w^{1}, \delta w^{2}, u\right)+i(\delta)+g^{1}-w^{1} \ell^{1}\left(1, \delta, w^{1}, \delta w^{2}, u\right)\right], \\
& E *\left(1, \delta \star, w \star^{l}, \delta w^{*}, u *\right)+i *(\delta *)+g \star^{1}+\delta \star g *^{2}=\delta * h \star(i *(\delta *)), \\
& c^{1}\left(1, \delta, w^{1}, \delta w^{2}, u\right)+i(\delta)+g^{1}+c^{*^{1}}\left(1, \delta *, w^{1}, \delta w^{*}, u^{*}\right)+1 *(\delta *)+g \star^{1} \\
& =w^{1} \ell^{1}\left(1, \delta, w^{1}, \delta w^{2}, u\right)+w^{\star^{1}} \ell^{\star^{1}}\left(1, \delta w^{*}{ }^{1}, \delta w^{\star^{2}}, u^{\star}\right), \\
& \delta=\delta * /(1+\theta)
\end{aligned}
$$

Consider the Impact on the world economy of a temporary increase in first period domestic government expenditure, $g l$. By undertaking the required comparative statics exercise on the system of equations (Al) to (A4) one obtains

$$
\frac{d \delta^{*}}{d g^{1}}=\frac{-\left(1-c_{W}^{1}-y_{W}^{1}\right)}{\left[(d b / d \delta)_{U}+\left(b / \delta^{*}\right)\left(c_{W}^{1}+y_{W}^{1}\right)\right] /(1+\theta)+\left[1-(\theta /(1+\theta))\left(c_{W}^{1}+y_{W}^{1}\right)\right]\left(d b^{*} / d \delta^{*}\right)}<0,
$$


30

$$
\mathrm{d} \delta / \mathrm{dg}=[1 /(1+\theta)]\left(\mathrm{d} \delta \star / \mathrm{dg} \mathrm{g}^{1}\right)<0,
$$

$$
\begin{gathered}
\left.d u / d g^{l}=-\left\{1+\left[\theta+\left(\delta * / b^{*}\right) /\left(d b^{*} / d \delta^{*}\right)\right]\left(d \delta^{*} / d g^{1}\right)\right\} / E_{u}\right\} 0, \\
d u * / d g^{*}=-\left[\left(b^{1} / \delta^{*}\right) / E_{u}^{*}\right]\left(d \delta * / d g^{1}\right)>0 \quad(\text { recall b }>0),
\end{gathered}
$$

where the sign of the denominator in (A5) follows from the assumption that in both the domestic and foreign countries current and future goods are gross substitutes, ie. $\left[(d b / d \delta)_{u}+\left(b / \delta^{*}\right)\left(c_{w}^{1}+y_{w}^{1}\right)\right] /(1+\theta) \equiv d b / d \delta^{*}>0$ and $d b * / d \delta^{*}>0$. The results for the perfect capital mobility case are easily obtained from the above expressions by setting $\theta=0$. This case is considered from here on.

Finally, the effects of the temporary change in domestic government expenditure on $c^{1}, y^{1}, c^{*}$ and $y^{*^{1}}$ are:

$$
\begin{aligned}
& \mathrm{dc} c^{1} / \mathrm{dg}{ }^{1}=\left(c_{\delta}^{1}+w^{2} c_{\delta w}^{1}\right)\left(\mathrm{d} \delta / d g^{1}\right)+c_{u}^{1}\left(d u / d g^{1}\right)<0, \\
& d y^{1} / d g^{1}=w^{1}\left(\ell_{\delta}^{1}+w^{2} \ell_{\delta w}^{1}\right)\left(d \delta / d g^{1}\right)+w^{1} \ell_{u}^{1}(d u / d g)>0, \\
& \left.d c^{*} / d g^{1}=\left[\left(c_{\delta}^{*}+w \star^{2} c_{\delta w}^{k^{1}}\right)-(b / \delta)^{*}\right) w_{w}^{1}\right]\left(d \delta \star / d g^{1}\right)<0,
\end{aligned}
$$

and

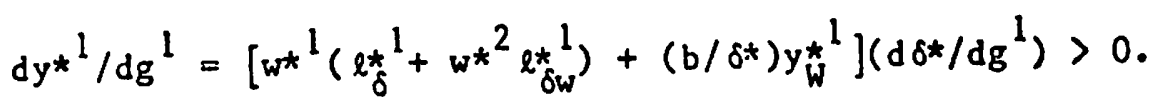

Note that under the maintained hypothesis that the domestic country is a net debtor on world markets, both substitution and income effects work to decrease home current consumption and increase output. For the foreign country the substitution effects also operate to curtail current consumption and stimulate 
output but the wealth effect works in the opposite direction. Following the standard macroeconomic presumption, it is assumed that an intertemporal price change's substitution effect dominates its income effect. Therefore, current consumption falls and output rises in both countries and positive comovement in macroeconomic aggregates occurs. Trivially, the effects of a temporary increase in foreign government expenditure on macroaggregates and real interest rates can be deduced by permuting the superscripts in equations (A5)-(A8). A more complete discussion of the perfect capital mobility case is contained in Greenwood and Kimbrough (1984b); see also Frenkel and Razin (1985a). 
32

Appendix B

From the domestic consumption function it follows immediately that

$$
d c^{1} / d g \star^{1}=\left(c_{\delta}^{1}+w^{2} c_{\delta w}^{1}\right)\left(d \delta / d g \star^{1}\right)+c_{u}^{1}\left(d u / d g \star^{1}\right) .
$$

After substituting (20) and (21) into this expression it can be seen that

$$
d c^{1} / d g^{1}=-\left[\left(c_{\delta}^{1}+w^{2} c_{\delta w}^{1}\right)\left(c_{W}^{1}+y_{W}^{1}\right)-c_{W}^{1}(d b / d \delta)_{u}\right]\left[\delta \tilde{b} /(\delta *)^{2}(d b / d \delta)_{u}\right]\left(d \delta^{*} / d g^{*}\right)
$$

Since $(d b / d \delta)_{u}=c_{\delta}^{1}+w^{2} c_{\delta w}^{1}+i_{\delta}-w^{1}\left(l_{\delta}^{1}+w^{2} l_{\delta w}^{1}\right)$ this reduces to

$$
d c^{1} / d g \star^{1}=-\left\{y_{W}^{1}\left(c_{\delta}^{1}+w^{2} c_{\delta w}^{1}\right)-c_{W}^{1}\left[i_{\delta}-w^{1}\left(\ell_{\delta}^{1}+w^{2} \ell_{\delta w}^{1}\right)\right]\right\}\left[\delta \tilde{b} /(\delta *)^{2}(d b / d \delta)\right]\left(d \delta * / d g \star^{1}\right)
$$

However, when preferences are time separable, $-c_{\delta}^{1} / w^{1} \ell_{\delta}^{l}=c_{W}^{1} / y_{W}^{1}=-c_{\delta w}^{1} / w^{1} \ell_{\delta w}^{l}$ as shown by Burro and King (1984). Therefore, $y_{W}^{1}\left(c_{\delta}^{1}+w^{2} c_{\delta w}^{1}\right)$

$+c_{w}^{1} w^{1}\left(\ell_{\delta}^{1}+w^{2} Q_{\delta w}^{1}\right)=0$ and the preceding expression reduces to

$$
d c^{1} / d \star^{1}=\left[c_{w^{i} \delta}^{1} \delta \tilde{b} /(\delta)^{2}(d b / d \delta)_{u}\right]\left(\lambda \delta / d g \star^{1}\right)<0
$$

as was to be shown. 


\section{Footnotes}

${ }^{1}$ The assumption that government expenditure is unproductive is not as restrictive as it may appear. Without altering any qualitative results the model can easily be extended to allow government purchases to yield consumption services and production benefits to agents. For a discussion of the general considerations involved in modelling government expenditure along these lines see Kimbrough (1984, 1985) and Aschauer and Greenwood (1985). Detalls in the presence of capital controls are contained in Greenwood and KImbrough (1984b). ${ }^{2}$ Svensson and Razin (1983) focus on the consumer's expenditure function and employ a similar method of analysis in their study of the impact of shifts in the terms-of-trade on the current account.

${ }^{3}$ This notion underlies the results in Obstfeld's (1984) example where a devaluation has real effects under dual exchange rates. ${ }^{4}$ The numerator of this term can be written as $1-\left(c_{W}^{1}+y_{W}^{1}\right)\left(1-\frac{\delta}{\delta^{\star}}\right)$ $=1-\left(c_{W}^{l}+y_{W}^{l}\right)\left(\frac{r-r^{*}}{1+r}\right)$ where $\left(\frac{r-r^{*}}{1+r}\right)$ is the wealth increase associated with relaxing capital controls. Easing capital controls by a unit increases the supply of current goods available domestically by the additional unit than can be borrowed internationally, while it increases spending on current goods by $c_{W}^{1}+y_{W}^{1}$ times the resulting increase in wealth. Thus, $1-\left(c_{W}^{1}+y_{W}^{1}\right)\left(\frac{r-r^{*}}{1+r}\right)$ is the excess supply of goods at the Initial real interest rate that results from loosening capital controls. 5 From equations ( 8$),(9)$ and the definition of $d b^{*} / d \delta^{*}$ it is easy to deduce that both $\delta^{*}$ and $d b^{*} / d \delta^{*}$ are functions of $\tilde{b}$ and the exogenous levels of foreign government purchases, $g^{1}$ and $g^{*^{2}}$. Similarly, from (6) and (7) it can be seen that $\delta$ is a function of $\tilde{b}$ and the exogenous levels of domestic government purchases, $\mathrm{g}^{\mathrm{l}}$ and $\mathrm{g}^{2}$. Consequently, it follows that by manipu- 
lating the target level of the capital account, $\tilde{b}$, the government can effectively set $\delta * / \delta-1=-(b * / \delta *)(d \delta * / d b *)$ as required by the optimum tariff rule.

${ }^{6}$ of course, these results could also hold if the tax equivalent of capital controls was below but sufficiently close to the optimum level so that substitution effects dominate wealth effects.

7 From equation (A5) $1 t$ can be seen that when $\theta=0, d \delta * / d^{1}=$ $-1 /\left[(d b / d \delta)_{u}+(b / \delta *)\left(c_{W}^{1}+y_{W}^{1}\right)+(d b * / d \delta *)\right]$ while with capital controls $d \delta * / d g^{l}=-1 /(d b * / d \delta *)$. The statement made in the text follows from the fact $(d b / d \delta)_{u}+(b / \delta *)\left(c_{W}^{1}+y_{W}^{l}\right)+(d b * / d \delta *)>d b * / d \delta *$, at least when the unconstrained $b$ is in the neighborhood of $\tilde{b}$. ${ }^{8}$ The formal argument is essentially the same as in footnote 7 . ${ }^{9}$ There is of course no reason to believe that preferences are Indeed time separable. This type of preference structure, while analytically convenient, has been criticized on the grounds that it restricts the amount of intertemporal substitution of consumption and leisure that can occur in response to relitive price changes--again, see Barro and King (1984). Throughout the paper the role of intertemporal substitution effects has been stressed and the assumption of time separable preference was not imposed. The assumption of time separable preferences is employed in the current example to stress the role of domestic investment in smoothing consumption and lelsure ncross time in an economy with capital controls.

${ }^{10}$ Kecent discussions along these lines in an open economy context include Kizin nnd Sivinsson (1983) and Kimbrough (1984). 


\section{References}

Adams, Charles and Greenwood, Jeremy. "Dual Exchange Rate Systems and Capital Controls: An Investigation," Journal of International Economics (1985): forthcoming.

Aschauer, David and Greenwood, Jeremy. "Macroeconomic Effects of Fiscal

Policy." Research Report 8501, University of Western Ontario, London, Ontar10, January 1985: Carnegie-Rochester Conference Serles on Public Policy, forthcoming.

Barro, Robert J. "Are Government Bonds Net Wealth?" Journal of Political Economy 82 (November/December 1974):1095-1117. - "On the Determination of the Public Debt." Journal of Polltical Economy 87 (October 1979):940-71. and King, Robert G. "Time Separable Preferences and Intertemporal-

Substitution Models of Business Cycles," Quarterly Journal of Economics, 99 (November 1984):817-839.

Darby, Michael R., et al. The International Transmission of Inflation.

Chicago: University of Chicago Press, 1983.

Frenkel, Jacob A. and Razin, Assaf. "Fiscal Policies, Debt, and International Economic Interdependence." Economic Journal, 1985(a). and __ "Fiscal Policies in the World Economy." Unpublished manuscript, University of Chicago, Chicago, IL, 1985(b).

Greenwood, Jeremy and Kimbrough, Kent P. "An Investigation in the Theory of Foreign Exchange Controls." Working Paper 8431, Centre for the Study of International Economic Relations, University of Western Ontario, London, Ontario, $1984(a)$. 
- Capital Controls and the International Transmission of Fiscal

Policy." Working Paper 8432, Centre for the Study of International

Economic Relations, University of Western Ontario, London, Ontario, $1984(b)$.

Kimbrough, Kent P. "Foreign Aid and Optimal Fiscal Policy." Unpublished

manuscript, Duke University, Durham, N.C., 1984.

- An Examination of the Effects of Government Purchases in an Open

Economy," Journal of International Money and Finance 4 (March 1985):

forthcoming.

Morgenstern, Oskar. International Financial Transactions and Business

Cycles. Princeton: Princeton University Press, 1959.

Mundel1, Robert A. "Capital Mobility and Stabilization Policy under Fixed and Flexible Exchange Rates." Chapter 18 in his International Economics, New York: Macmillan, 1968.

Obstfeld, Maurice. "Capital Controls, the Dual Exchange Rate, and Devalua-

tion." Working Paper 8423, Centre for the Study of International Economic Relations, University of Western Ontario, London, Ontario, 1984.

Persson, Torsten. "Global Effects of National Stabilization Policies under

Fixed and Floating Exchange Rates." Scandinavian Journal of Economics 84 $(1982): 165-92$

- "Deficits and Intergenerational Welfare in Open Economies." NBER

Working Paper No. 1083, 1983.

Razin, Assaf and Svensson, Lars E. 0. "The Current Account and the Optimal

Government Debt." Journal of International Money and Finance 2 (August 1983):215-24.

Svensson, Lars E. 0. and Razin, Assaf. "The Terms of Trade and the Current Account: The Harberger-Laursen-Metzler Effect," Journal of Polltical Economy 91 (Eebruary 1983):97-125. 